\title{
Phenotypic and genotypic detection of antibiotic resistance of Pseudomonas aeruginosa isolated from urinary tract infections
}

\author{
Hisham A Abbas ${ }^{1}$, Amira M El-Ganiny ${ }^{1}$, Hend A Kamel ${ }^{1,2}$
}

1. Microbiology and Immunology Department, Faculty of Pharmacy, Zagazig University, Zagazig, Egypt. 2. Microbiology Department, Faculty of Pharmacy and Pharmaceutical Industries, Sinai University, Kantara, Egypt.

\begin{abstract}
Bakground: Pseudomonas aeruginosa is a major nosocomial uropathogen. It can tolerate a wide variety of physical conditions and many antibiotics by different resistance mechanisms.

Objectives: This study aimed to investigate the mechanisms of antibiotics resistance in uropathogenic $P$. aeruginosa clinical isolates.

Methods: Two hundred sixty six urine samples were collected from Zagazig University Hospitals, Zagazig, Egypt. P. aeruginosa isolates were identified using standard microbiological tests. The sensitivity to different antibiotics was determined by disc diffusion method. Anti-microbial resistance mechanisms were investigated using phenotypic methods and confirmed by PCR.

Results: Fifty P. aeruginosa isolates were recovered. All isolates were MDR and were resistant to amoxicillin/clavulinic, sulphamethaxzole/trimethoprim, doxycycline and ceftazidime. Phenotypic detection of resistance mechanisms revealed that all strains have efflux mechanism, outer membrane porins, and AmpC $\beta$-lactamase; none of the strains showed ESBL activity and two of the imipenem resistant strains showed M $\beta L$ activity. PCR analysis showed that all strains have MexAB-R, OprD and AmpC genes, 42 strains had PSE gene, while VEB and VIM genes were not detected.

Conclusion: The resistance rates in $P$. aeruginosa were higher than global values; this resistance was attributed to several mechanisms. This high resistance is alarming and necessitates applying strict antibiotic prescription policies.

Keywords: Pseudomonas aeruginosa, urinary tract infections, antibiotic resistance, resistance mechanisms.

DOI: https://dx.doi.org/10.4314/ahs.v18i1.3

Cite as: Abbas HA, El-Ganiny AM, Kamel HA. Phenotypic and genotypic detection of antibiotic resistance of Pseudomonas aeruginosa isolated from urinary tract infections. Afri Health Sci 2018;18(1): 11-21. https:// dx.doi.org/10.4314/abs.v18i1.3
\end{abstract}

\section{Introduction}

Pseudomonas aeruginosa is one of the most ecologically significant species among the genus Pseudomonas. P. aerugino$s a$ is of extreme importance because of the widespread distribution of its strains in nature, its high intrinsic anti-bacterial resistance and its virulence ${ }^{1}$.

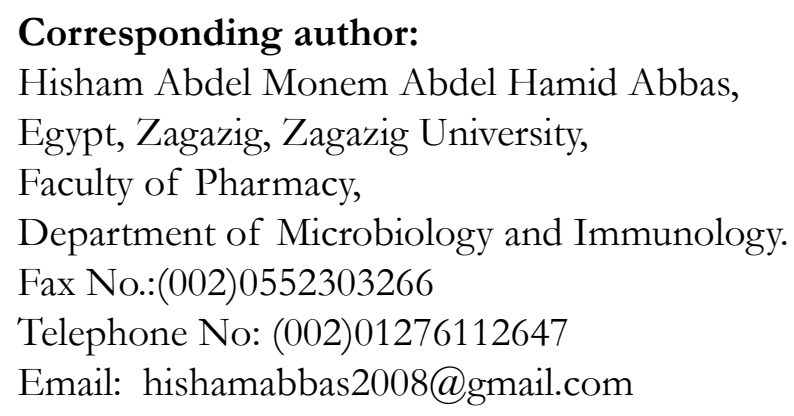

P. aeruginosa is an opportunistic, hospital-acquired pathogen that causes severe diseases in immuno-compromised individuals including urinary tract infection. Urinary tract infections (UTIs) are some of the most frequent bacterial infections, affecting 150 million people annually worldwide $^{2}$. P. aeruginosa is the third most common pathogen associated with nosoomial catheter-associated UTIs ${ }^{3}$. Despite advances in anti-microbial therapy, the mortality and morbidity associated with $P$. aeruginosa induced UTIs remain significantly high ${ }^{4}$. One key reason for therapy failure is the increased level of antibiotic resistance among clinical $P$. aeruginosa isolates 5 . Thus, the detection of the underlying resistance mechanisms is critical for better management of this problem.

Many antibiotic resistance mechanisms have been reported in P. aeruginosa including: 1) Reduced expression or loss

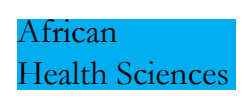

@ 2018 Abbas et al; licensee African Health Sciences. This is an Open Access article distributed under the termsof the Creative commons Attribution License (https://creativecommons.org/licenses/by/4.0), which permits unrestricted use, distribution, and reproduction in any medium, provided the original work is properly cited. 
of OprD porin causing reduced antibiotic permeability ${ }^{6}$, 2) Over-expression of MexAB-OprM pump which increases antibiotic efflux ${ }^{7}, 3$ ) Production of $\beta$-lactams and aminoglycosides inactivating enzymes ${ }^{8}$, 4) Mutations of gyrases and topoisomerases which causes fluoroquinolone resistance ${ }^{9}$. These mehanisms in combination lead to multiple drug resistance ${ }^{10}$.

$\beta$-lactamases are hydrolytic enzymes that are responsible for the resistance to $\beta$-lactam antibiotics. $\beta$-lactamases have many types including extended spectrum $\beta$-lactamases (ESBLs), AmpC $\beta$-lactamases, carbenicillin hydrolysing $\beta$-lactamase, Pseudomonas specific enzyme (PSE) and metallo- $\beta$-lactamases $(\mathrm{M} \beta \mathrm{Ls})^{11-13}$. ESBLs are encoded by different genes in $P$. aeruginosa including VEB gene ${ }^{11}$. M $\beta$ Ls are encoded by different genes including VIM (Verona Integron-encoded Metallo- $\beta$-lactamase) and IMP ${ }^{14}$.

Bacterial efflux pumps are greatly involved in the intrinsic resistance of Gram-negative bacteria. When overexpressed, efflux pumps can confer high resistance to previously effective antibiotics. Many efflux pumps transport a wide range of unrelated drugs and are known as multidrug resistance (MDR) efflux pumps. Four antibiotic efflux systems have been reported in $P$. aeruginosa. Mex$\mathrm{AB}-\mathrm{OprM}$ is the efflux system that is responsible for extrusion of $\beta$-lactams and quinolones ${ }^{15}$.

The outer membrane of $P$. aeruginosa represents a significant barrier that hinders the penetration of antibiotics. $\beta$-lactams and quinolones can only cross the outer membrane through the porin proteins. $P$. aeruginosa produces several porins such as OprD and OprF. Loss or diminished expression of $\mathrm{OprD}$ are frequently related to mipenem resistance $i^{16}$.

This study was performed to detect antibiotic resistance profile of local $P$. aeruginosa isolated from urinary tract infections and to determine the underlying resistance mechanisms by phenotypic and genotypic methods.

\section{Material and methods}

\section{Media and chemicals}

Mueller Hinton broth, Mueller Hinton agar and antibiotic discs were purchased from Oxoid (Hampshire, UK). Ethidium bromide was obtained from Merck, Hohen- burnn, Germany. MyTaqTM master mix was the product of Bioline Reagents Limited, UK, while Gene-Ruler 100 bp DNA Ladder was purchased from Thermoscientific Inc, USA. Other chemicals were of pharmaceutical grade.

\section{Bacterial strains}

A total of 266 urine samples were collected from patients with urinary tract infections admitted to Urology Department, Zagazig University hospitals, Zagazig, Egypt. Only one sample was collected per patient. Samples were collected from clean-catch midstream fresh urine in sterile plastic jars. Samples were immediately transported to the Microbiological laboratory at Faculty of Pharmacy, Zagazig University, where they were immediately processed. $P$. aeruginosa identification was based on standard microbiological technique including: Gram staining, colony morphology, motility, pigment production, oxidase reaction, growth at $42{ }^{\circ} \mathrm{C}$, gelatin liquefaction test and sugar utilization tests ${ }^{17}$.

\section{Anti-microbial susceptibility testing:}

Anti-microbial susceptibility testing was performed on Mueller Hinton agar (MHA) plates by disc diffusion method and interpreted according to Clinical Laboratory Standards Institute guidelines $(\mathrm{CLSI})^{18}$. The tested classes of antibiotics were penicillins, carbapenems, cephalosporins, $\beta$-lactam/ $\beta$-lactamase inhibitor combination, aminoglycosides, tetracyclines, chloramphenicol, sulphonamides and fluoro-quinolones. The antibiotic discs included amikacin $(30 \mu \mathrm{g})$, gentamicin $(10 \mu \mathrm{g})$, piperacillin/tazobactam $(100 / 10 \mu \mathrm{g})$, imipenem $(10 \mu \mathrm{g})$, ceftazidime $(30 \mu \mathrm{g})$, cefoperazone $(10 \mu \mathrm{g})$, cefotriaxone $(30 \mu \mathrm{g})$, cefotaxime $(30 \mu \mathrm{g})$, cefepime $(30 \mu \mathrm{g})$, amoxicillin/clavulanic acid 2:1 $(30 \mu \mathrm{g})$, ciprofloxacin $(5 \mu \mathrm{g})$, levofloxacin $(5 \mu \mathrm{g})$, chloramphenicol $(30 \mu \mathrm{g})$, doxycycline $(30 \mu \mathrm{g})$, pipracillin $(100 \mu \mathrm{g})$ and sulphamethoxazole / trimethoprim $(1.25 / 23.75 \mu \mathrm{g})$.

\section{Phenotypic detection of resistance mechanisms: Phenotypic detection of $\mathrm{M} \beta \mathrm{L}$ activity:}

The imipenem-resistant $P$. aeruginosa isolates were investigated for $\mathrm{M} \beta \mathrm{L}$ production by imipenem-Ethylene diamine tetra acetic acid combined disc test (IMP-EDTA CDT) as described previously by Yong et al. ${ }^{19}$ Briefly, overnight culture of the test organism was prepared and its turbidity was adjusted to a $0.5 \mathrm{McF}$ arland standard and surface inoculated on MHA plate (9 $\mathrm{cm}$ in diameter). Two 
imipenem discs $(10 \mu \mathrm{g})$ were placed at a distance of $4-5$ $\mathrm{cm}$ from each other on the plate, and amount of $10 \mu \mathrm{L}$ of $0.5 \mathrm{M}$ EDTA solution was added to one of them. The inhibition zones of the imipenem and imipenem-EDTA discs were compared after $18 \mathrm{~h}$ of incubation at $35^{\circ} \mathrm{C}$. Isolates were considered as M $\beta L$ positive if the zone diameter of imipenem-EDTA disc was larger by more than or equal to $7 \mathrm{~mm}$.

\section{Phenotypic detection of AmpC $\beta$-lactamases pro- duction:}

AmpC $\beta$-lactamase production was phenotypically detected on the isolates that were resistant to cefoxitin according to Vanwynsberghe et al. ${ }^{20}$ Briefly, ceftazidime (30 $\mu \mathrm{g})$ and cefotaxime $(30 \mu \mathrm{g})$ disks were each placed at a distance of $20 \mathrm{~mm}$ from cefoxitin $(30 \mu \mathrm{g})$ disk on a 9 cm-diameter MHA plate inoculated with the test $P$. aeruginosa isolate. The production of AmpC enzyme was confirmed when the zones of inhibition produced by either of the cephalosporins (ceftazidime or cefotaxime) when used in conjunction with cefoxitin were $\geq 5 \mathrm{~mm}$ larger than cephalosporins inhibition zone alone.

\section{Phenotypic detection of extended spectrum $\beta$-lact- amases (ESBL) production:}

A lawn culture of the organisms was made on a $9 \mathrm{~cm}$-diameter MHA plate, as recommended by $\mathrm{CLSI}^{21}$. A disc which contained ceftazidime-clavulanate $(30 / 10 \mu \mathrm{g})$ and ceftazidime discs $(30 \mu \mathrm{g})$ were placed at distance of 20 $\mathrm{mm}$. After an overnight incubation at $37^{\circ} \mathrm{C}$, an increase of $5 \mathrm{~mm}$ in zone of inhibition of the combination discs in comparison to the ceftazidime disc alone was considered to be ESBL producer.

\section{Phenotypic detection of efflux pumps by ethidium bromide cartwheel (EtBr-CW) method}

The ability of efflux pumps to expel ethidium bromide was assessed according to EtBr-CW method ${ }^{22}$. Trypticase Soya Agar (TSA) plates containing EtBr ranging from 0 to $4 \mathrm{mg} / \mathrm{L}$ (these concentrations were determined according to the bacterial MICs of EtBr) were freshly prepared on the same day of the experiment and kept protected from light. Overnight cultures of the tested bacterial isolates were prepared and adjusted to a $0.5 \mathrm{McF}$ arland turbidity standard. The $9 \mathrm{~cm}$-diameter TSA plates were divided into ten to twelve sectors forming a cartwheel pattern.
The adjusted bacterial cultures were swabbed on the EtBr-TSA plates starting from the center of the plate to the margin. After incubation of the plates at $37^{\circ} \mathrm{C}$ for 16 $\mathrm{h}$, the plates were examined under UV transilluminator (Cole-parmer, Vemon Hills, USA), the minimum concentration of $\mathrm{EtBr}$ that produced fluorescence of the bacterial mass was recorded. The isolates were considered Et$\mathrm{Br}-\mathrm{CW}$-negative if they showed emission of fluorescence at $0.5-1 \mathrm{mg} / \mathrm{L} \mathrm{EtBr}, \mathrm{EtBr}-\mathrm{CW}$ intermediate (emitting fluorescence at $2 \mathrm{mg} / \mathrm{L}$ ) or EtBrCW-positive (emitting fluorescence only at 3-4 mg/L).

\section{Phenotypic detection of outer membrane permea- bility (OMP)}

Assessment of MDR bacteria for OMP was performed by determination of the minimum inhibitory concentration (MIC) values for selected antibiotics in the presence and absence of EDTA ( $\mathrm{pH}=7.2)$; a permeabilizer which chelates divalent cations that stabilize molecular interactions in the OM causing disruption of OMP. To avoid the effect of EDTA on bacterial growth, it was used at a concentration of $1 / 4$ MIC. A four-fold reduction in the antibiotic MIC or more in the presence of EDTA indicates $\mathrm{OM}$ reduced permeability activity.

The MICs of antibiotics and EDTA were determined by broth micro-dilution according to CLSI guidelines ${ }^{23}$. Müller Hinton broth (MHB) was inoculated with colonies of $P$. aeruginosa and broth was incubated with shaking at $37^{\circ} \mathrm{C}$ until the turbidity became equivalent to $0.5 \mathrm{McFar}-$ land standard. Then the bacterial suspension was diluted 1:100 in MHB medium. Two-fold serial dilutions of each drug were prepared in 96 wells microtiter plates in a final volume of $100 \mu \mathrm{L}$ per well. Each well was inoculated with $100 \mu \mathrm{L}$ of the previously prepared bacterial suspension and incubated at $37^{\circ} \mathrm{C}$ for $18-20 \mathrm{~h}$. MIC was defined as the lowest concentration of drug at which there was no visible growth of the organism. The results were recorded and interpreted according to CLSI ${ }^{23}$.

\section{Genotypic detection of resistance mechanisms by PCR.}

The gDNA was extracted by picking a colony from an agar plate using a sterile pipette tip and resuspending it into $20 \mu \mathrm{L}$ of distilled water. The mixture was vortexed for $10 \mathrm{~s}$ then incubated at $98^{\circ} \mathrm{C}$ for $5 \mathrm{~min}$. The lysate was 
centrifuged and the resulting supernatant was collected, diluted with distilled water at a 1:3 dilution ratio, and subjected to PCR analysis. Each PCR mixture contained 10 $\mu \mathrm{L}$ of MyTaqTM master mix; $1.5 \mu \mathrm{L}$ of forward primer, $1.5 \mu \mathrm{L}$ of reverse primer, $2 \mu \mathrm{L}$ of gDNA template and nuclease free water to $20 \mu \mathrm{L}$. The primers used in this study are listed in Table 1. The PCR was performed in Biometra T-personal thermocycler (Goettingen, Germany). The PCR products as well as Gene-Ruler $100 \mathrm{bp}$ DNA Ladder were separated on 1\% agarose gel, stained with $2 \mu \mathrm{L}$ of $\mathrm{EtBr}$, and visualized by $\mathrm{UV}$ transilluminator and photographed.

Detection of Mex-ABR genes was done according to Al-Grawi et al. ${ }^{24}$ The cycling conditions were initial heating at $94^{\circ} \mathrm{C}$ for $3 \mathrm{~min}$, then 32 cycles of $94^{\circ} \mathrm{C}$ for $30 \mathrm{sec}$, $57^{\circ} \mathrm{C}$ for $45 \mathrm{sec}$ and $72^{\circ} \mathrm{C}$ for $1 \mathrm{~min}$ and final extension at $72^{\circ} \mathrm{C}$ for $7 \mathrm{~min}$. OprD gene detection was performed according to Rodríguez-Martínez et al. ${ }^{25}$ and included heating at $94{ }^{\circ} \mathrm{C}$ for $2 \mathrm{~min}$, then 29 cycles of $94^{\circ} \mathrm{C}$ for $20 \mathrm{sec}$, $51{ }^{\circ} \mathrm{C}$ for $30 \mathrm{sec}$ and $70{ }^{\circ} \mathrm{C}$ for $30 \mathrm{sec}$ and final extension at $70{ }^{\circ} \mathrm{C}$ for $7 \mathrm{~min}$. AmpC gene detection was according to Fazeli et al. ${ }^{26}$ and included heating at $94{ }^{\circ} \mathrm{C}$ for $2 \mathrm{~min}$, then 29 cycles of $94{ }^{\circ} \mathrm{C}$ for $20 \mathrm{sec}, 52.3^{\circ} \mathrm{C}$ for $30 \mathrm{sec}$ and $70{ }^{\circ} \mathrm{C}$ for $15 \mathrm{sec}$ and final heating at $70^{\circ} \mathrm{C}$ for $7 \mathrm{~min}$. PSE gene detection was following Neyestanaki et al. ${ }^{27}$, heating at $94^{\circ} \mathrm{C}$ for $2 \mathrm{~min}$, then 29 cycles of $94^{\circ} \mathrm{C}$ for $20 \mathrm{sec}$, $48.8^{\circ} \mathrm{C}$ for $30 \mathrm{sec}$ and $70{ }^{\circ} \mathrm{C}$ for $45 \mathrm{sec}$ and finally heating at $70^{\circ} \mathrm{C}$ for $7 \mathrm{~min}$. VEB gene detection was according to Qing et al. ${ }^{28}$ and include heating at $94^{\circ} \mathrm{C}$ for $2 \mathrm{~min}$, then 30 cycles of $94^{\circ} \mathrm{C}$ for $20 \mathrm{sec}, 52.4^{\circ} \mathrm{C}$ for $30 \mathrm{sec}$ and 70 ${ }^{\circ} \mathrm{C}$ for $45 \mathrm{sec}$ and finally heating at $70{ }^{\circ} \mathrm{C}$ for $7 \mathrm{~min}$. VIM gene detection included heating at $94^{\circ} \mathrm{C}$ for $2 \mathrm{~min}$, followed by 29 cycles of $94{ }^{\circ} \mathrm{C}$ for $20 \mathrm{sec}, 51^{\circ} \mathrm{C}$ for $30 \mathrm{sec}$ and $70{ }^{\circ} \mathrm{C}$ for $30 \mathrm{sec}$ and final heating at $70^{\circ} \mathrm{C}$ for $7 \mathrm{~min}^{29}$.

\section{Results}

\section{Antimicrobial susceptibility}

Only 50 P. aeruginosa strains were recovered from the 266 urine samples $(18.7 \%)$. The resistance rates of $P$. aeruginosa isolates to the tested antibiotics were presented in Figure 1.

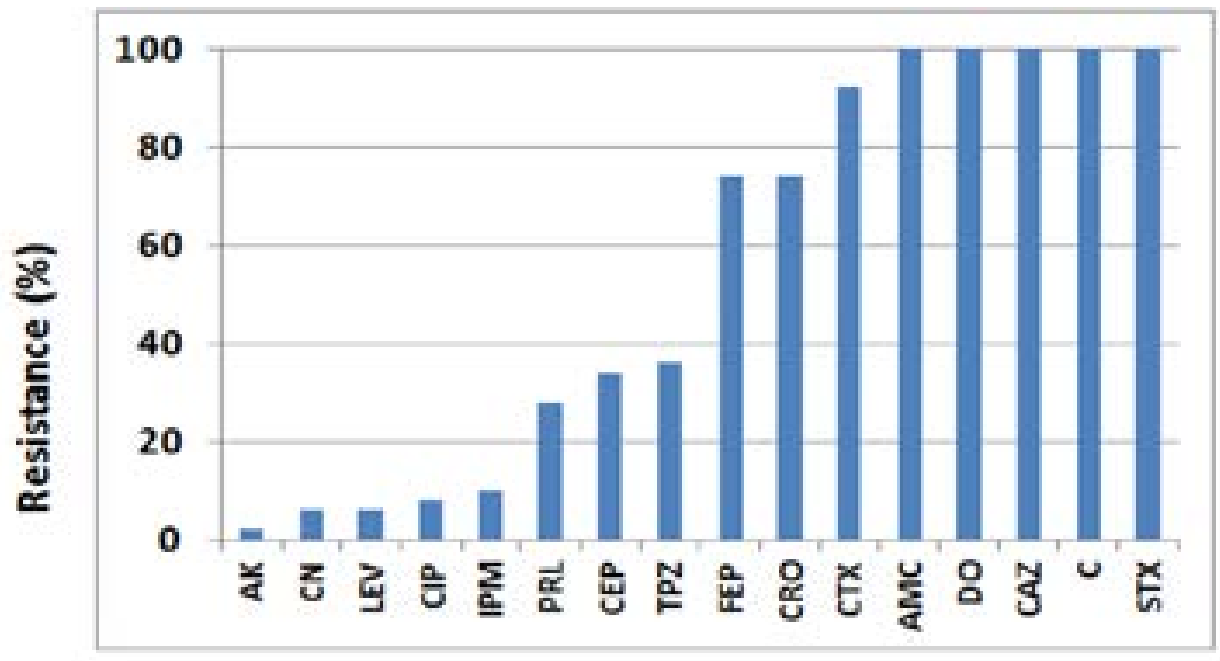

Antibiotics

Figure 1. The antibiotic resistance of $P$. aeruginosa isolates.

All the isolates were resistant to amoxicillin/clavulanic, sulphamethoxazole/ trimethoprim, doxycycline, chloramphenicol and ceftazidime. Resistance to cefotaxime was $92 \%$ and $74 \%$ for ceftriaxone and cefepime, respec- tively. The isolates showed low resistance to amikacin $(2 \%)$, gentamicin $(6 \%)$, levofloxacin $(6 \%)$, ciprofloxacin $(8 \%)$ and imipenem $(10 \%)$. All of the P. aeruginosa isolates were multidrug resistant (MDR). The resistance pattern of the $P$. aeruginosa isolates was shown in Table 2. 
Table 1. Primer sequence and amplicon size

\begin{tabular}{|c|c|c|c|}
\hline Target gene & Primer sequence & $\begin{array}{c}\text { Product size } \\
(\mathrm{bp})\end{array}$ & Reference \\
\hline $\operatorname{mexA-F}$ & CTCGACCCGATCTACGTC & 503 & Al-Grawi et $_{\text {al. }}{ }^{24}$ \\
\hline $\operatorname{mex} A-R$ & GTCTTCACCTCGACACCC & & \\
\hline mexR-F & GAACTACCCCGTGAATCC & 411 & Al-Grawi et al. ${ }^{24}$ \\
\hline mexR-R & CACTGGTCGAGGAGATGC & & \\
\hline mexB-F & TGTCGAAGTTTTTCATTGATAG & & Al-Grawi et al..$^{24}$ \\
\hline mexB-R & AAGGTCAC GGTGATGGT & 280 & \\
\hline OprD-F & GCTCGACCTCGAGGCAGGCCA & 242 & Rodríguez-Martínezet al. ${ }^{25}$ \\
\hline OprD-R & CCAGCGATTGGTCGGATGCCA & & \\
\hline $\begin{array}{l}\text { AmpC-F } \\
\text { AmpC-R }\end{array}$ & GCTCCACCAACGGCTTCCTGAGGATGGCGTAGGC & 124 & Fazeli et al. ${ }^{26}$ \\
\hline $\begin{array}{l}\text { PSE-F } \\
\text { PSE-R }\end{array}$ & $\begin{array}{l}\text { AATGGCAATCAGCGCTTC } \\
\text { GCGCGACTGTGATGTATA }\end{array}$ & 698 & Neyestana et $a l .{ }^{27}$ \\
\hline $\begin{array}{l}\text { VEB-F } \\
\text { VEB-R }\end{array}$ & $\begin{array}{l}\text { CATTTCCCGATGCAAAGCGT } \\
\text { CGAAGTTTCTTTGGACTCTG }\end{array}$ & 648 & Qing et al. ${ }^{28}$ \\
\hline $\begin{array}{l}\text { VIM-F } \\
\text { VIM-R }\end{array}$ & $\begin{array}{l}\text { GATGGTGTTTGGTCGCATA } \\
\text { CGAATGCGCAGCACCAG }\end{array}$ & 390 & Poire et al. ${ }^{29}$ \\
\hline
\end{tabular}

Table 2. Antibiotic resistance pattern of the clinical $P$. aeruginosa isolates

\begin{tabular}{ll}
\hline Antibiotic resistance pattern & No of isolates \\
\hline CN, AK, LEV, CIP, IMP, TPZ, CEP, PRL, FEP, CRO, CTX, DO, & 1 \\
CAZ, C, STX, AMC & 1 \\
LEV, CIP, IMP, TPZ, CEP, PRL, FEP, CRO, CTX, DO, CAZ, C, & 1 \\
STX, AMC & 1 \\
LEV, CIP, IMP, TPZ, CN, CEP, FEP, CRO, CTX, DO, CAZ, C, & 11 \\
SPZ, CEP, PRL, FEP, CRO, CTX, DO, CAZ, C, STX, AMC & 11 \\
TPZ, CN, CIP, FEP, CRO, CTX, DO, CAZ, C, STX, AMC & 1 \\
TPZ, CEP, FEP, CRO, CTX, DO, CAZ, C, STX, AMC & 3 \\
TPZ, PRL, FEP, CRO, CTX, DO, CAZ, C, STX, AMC & 1 \\
IMP, FEP, CRO, CTX, DO, CAZ, C, STX, AMC & 1 \\
FEP, CRO, CTX, DO, CAZ, C, STX, AMC & 13 \\
CRO, CTX, DO, CAZ, C, STX, AMC & 4 \\
IMP, CTX, DO, CAZ, C, STX, AMC & 1 \\
FEP, CTX, DO, CAZ, C, STX, AMC & 2 \\
CTX, DO, CAZ, C, STX, AMC & 6 \\
FEP, DO, CAZ, C, STX, AMC & 2 \\
DO, CAZ, C, STX, AMC & 2 \\
\hline
\end{tabular}


Phenotypic detection of resistance mechanisms The IMP-EDTA-CDT was performed for the 5 imipenem resistant isolates and the results revealed that 2 of these isolates were $\mathrm{M} \beta \mathrm{L}$ producer (Fig. $2 \mathrm{~A}$ ). All the 50 MDR $P$. aeruginosa isolates were phenotypically confirmed to produce AmpC $\beta$-lactamase (Fig. 2 B). All the MDR isolates were subjected to qualitative assessment for ef- flux pumps by EtBr-CW method, and all of the tested isolates showed efflux pump activity (Fig. 2 C). None of the MDR P. aeruginosa isolates were ESBL producers (Fig. 2 D). EDTA was used for phenotypic detection of OMP; generally EDTA potentiated the effect of different antimicrobial agents as it reduced the tested antibiotics MICs as indicated in Table 3.

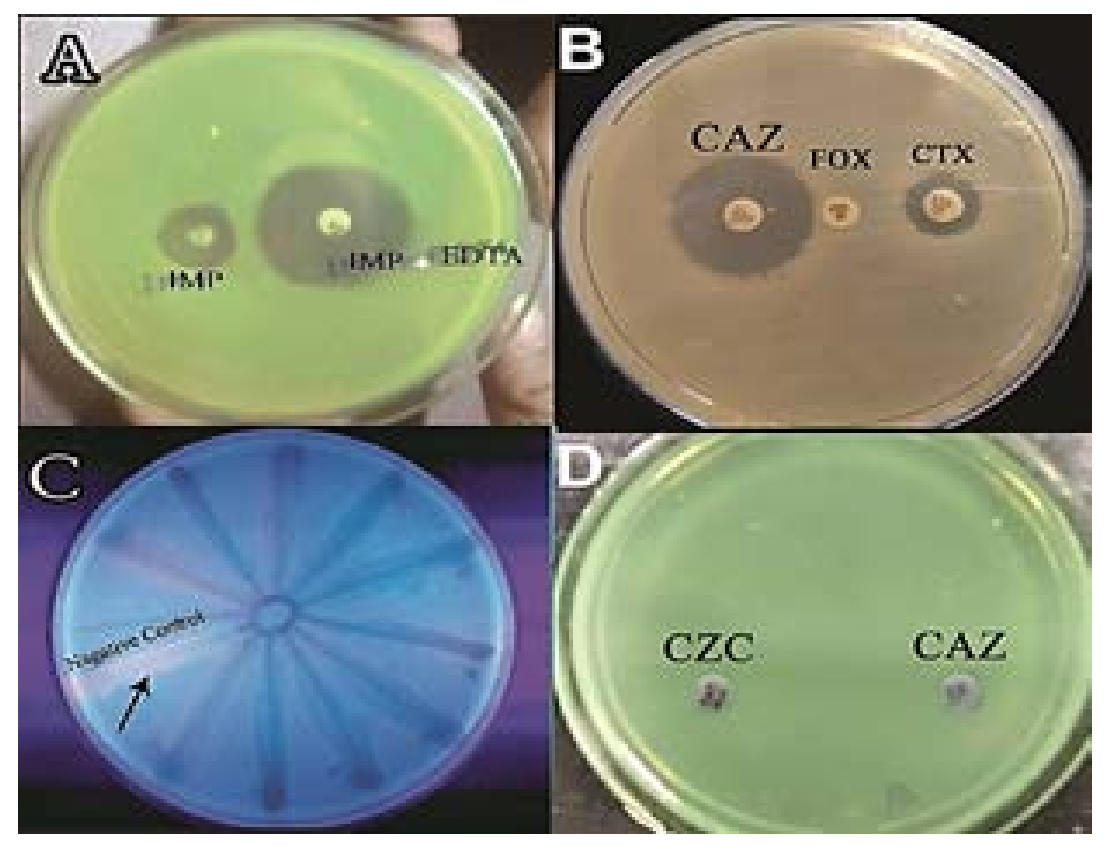

Figure 2. Phenotypic detection of resistance mechanisms. A, detection of M $\beta$ L by IMPEDTA-CDT method, positive isolates showed $\geq 7 \mathrm{~mm}$ increase in zone of inhibition in presence of EDTA; B, detection of AmpC $\beta$ - lactamase, positive isolates show that zones of inhibition produced by cephalosporins (CAZ or CXT) when used with cefoxitin (Fox) were $5 \mathrm{~mm}$ bigger than cephalosporins zone alone; $C$, detection of efflux pumps by EtBr-CW method, all the isolates did not show emission of fluorescence; $D$, detection of ESBL using ceftazidime (CAZ), and ceftazidime- clavulininc (CZC) discs, none of the isolates showed positive results.

Table 3. The MIC50 $(\mu \mathrm{g} / \mathrm{mL})$ of some antibiotics (without and with EDTA)

\begin{tabular}{lcc}
\hline Antibiotic & MIC50 & $\begin{array}{c}\text { MIC50 in presence of } \\
\text { EDTA }\end{array}$ \\
\hline Amikacin & 8 & 0.5 \\
levofloxacin & 2 & 0.125 \\
cefotaxime & 512 & 32 \\
ceftazidime & 1024 & 64 \\
\hline
\end{tabular}


Genotypic detection of resistance genes

PCR was used to detect resistance genes. Multiplex PCR was used for amplification of MexA-B-R genes encoding efflux pumps, all the MDR isolates gave a triple band at 280, 411 and 503 bp matching the Mex-B-R-A genes (Fig. 3 A).

For OprD gene encoding outer membrane porins, all of the MDR isolates gave a single band at $242 \mathrm{bp}$ match- ing OprD gene (Fig. 3 B). For amplification of AmpC gene encoding AmpC $\beta$-lactamase, all the MDR isolates gave a single band at $124 \mathrm{bp}$ matching the AmpC gene (Fig. 3 C). In case of PSE gene, 42 of the MDR isolates gave a single band at $698 \mathrm{bp}$ matching the PSE gene (Fig. 3 D). For VEB gene encoding ESBL enzyme and VIM gene encoding $\mathrm{M} \beta \mathrm{L}$, none of the tested isolates gave the $648 \mathrm{bp}$ band matched to VEB gene or the $390 \mathrm{bp}$ band matching VIB gene.

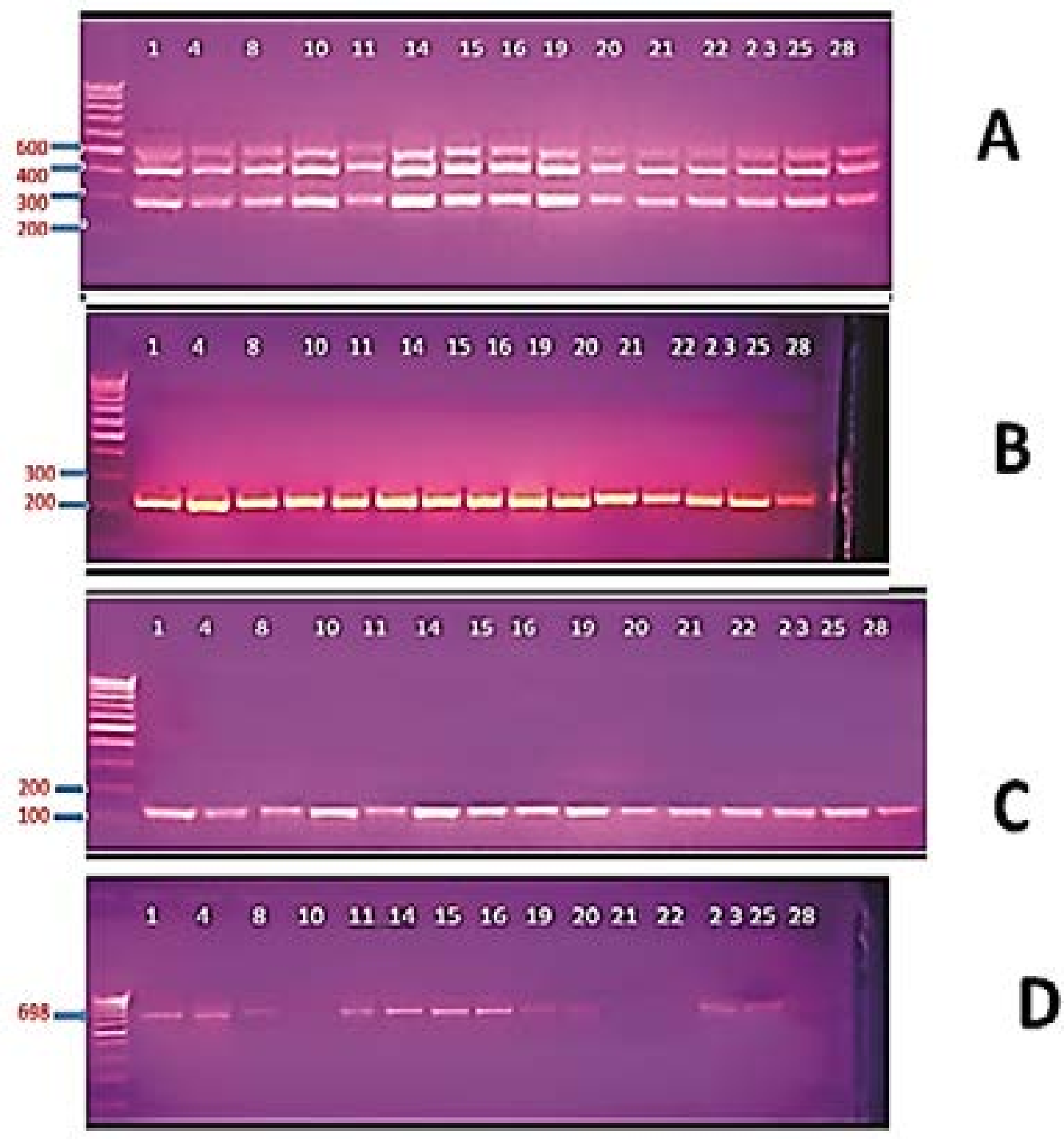

Figure 3. Gel electrophoresis of PCR products for detection of resistance genes genes in selected MDR isolates. A, detection of MexA-B-OprM genes, all the isolates gave triple bands of 280 bp, 411 bp and 503 bp representing MexB, MexR and MexA genes, respectively; B, detection of OprD gene, all isolates gave a single band at 242 bp; $C$, detection of AmpC gene, all the isolates gavea single band at 124 bp; D, detection of PSE gene, positive isolates gave a single band at 698 bp. 


\section{Discussion}

MDR isolates represents a prominent health problem in Egypt due to several factors including misuse of antibiotics and biocides ${ }^{30}$. In the current study, 50 P. aeruginosa isolates were recovered from urine samples, all the isolates were MDR (100\%), this MDR rate was higher than rates reported previously in Egypt which ranged from 34\% $56 \%{ }^{31-33}$; this may reflect higher resistance rate in case of urinary tract infections. Other global studies showed even lower MDR rates; 5.9\% in Canada ${ }^{34}, 19 \%$ in Germany ${ }^{35}$, $19.6 \%$ in Malaysia ${ }^{36}$ and $20.7 \%$ in $\mathrm{Nepal}^{37}$. This MDR rate is alarming and necessities application of strict antibiotic prescription policies in our country.

The resistance rates were low to amikacin (2\%), gentami$\operatorname{cin}(6 \%)$, levofloxacin $(6 \%)$, ciprofloxacin $(8 \%)$ and imipenem $(10 \%)$. Previous studies also reported that amikacin and imipenem were the most effective drugs against P. aeruginosa ${ }^{26,31}$. Higher resistance rates were reported for pipracillin (28\%), cefoperazone (34\%), piperacillin/tazobactam $(36 \%)$ cefotriaxone $(74 \%)$, cefepime $(74 \%)$, and cefotaxime $(92 \%)$, while all the isolates were resistant to ceftazidime, chloramphenicol, doxycycline, amoxicillin/ clavulanic and sulphamethoxazole/ trimethoprim. Selection of curative antibiotic should always depend on the results of antimicrobial susceptibility testing to avoid therapy failure. Inappropriate therapy has been associated with increased mortality in $P$. aeruginosa infections ${ }^{38}$.

In the current study, phenotypic detection of M $\mathrm{ML}$ production reveled that only 2 of the 5 imipenem resistant isolates (40\%) were M $\beta$ L-positive. A previous Egyptian study reported relatively similar results where $27 \%$ of $P$. aeruginosa were $\mathrm{M} \beta \mathrm{L}$ producers ${ }^{39}$. PCR analysis showed that VIM gene (encoding M $\mathrm{LL}$ ) was not detected in any of our isolates. High prevalence of VIM gene (58-61\%) was reported previously in $P$. aeruginosa ${ }^{40}$, Probably the $\mathrm{M} \beta \mathrm{L}$ activity in our study is attributed to other M $\beta \mathrm{L}$ genes or another mechanism. Several mechanisms of imipenem resistance have been reported previously including secretion of carbapenemases, increased expression of efflux systems, and reduced porin expression ${ }^{41}$. The isolation of carbapenem resistant strains is alarming and requires restriction on prescription of these valuable drugs

Phenotypic analysis showed that none of our isolates was an ESBL producer, this was comparable to the low occur- rence $(7.4 \%)$ reported previously in Egypt ${ }^{40}$. While Lin et $\mathrm{al}^{42}$ found that $29 \%$ of his strains were ESBL producers. PCR was used for detection of VEB gene encoding ESBLs, the gene was not detected in any of the isolate which is compatible with our phenotypic results. Zafer et al. $^{40}$ reported that $10.4 \%$ of ESBL-producing P. aeruginosa isolates were positive for $\mathrm{VEB}$ gene.

All of the tested isolates were AmpC $\beta$-lactamase producer. Chika et al. ${ }^{43}$ found that $36 \%$ of $P$. aeruginosa isolates were $\mathrm{AmpC}$ producers. The presence of $\mathrm{AmpC}$ -lactamase enzyme was confirmed by PCR, all of the $P$. aeruginosa isolates harbored the AmpC gene. Similarly, Fazeli et al. ${ }^{26}$ found that all the $P$. aeruginosa isolates had AmpC gene.

The Pseudomonas specific enzyme (PSE) belong to Class A carbenicillin hydrolysing $\beta$-lactamases that confer resistance to carbenicillin and pipracillin. The presence of PSE gene was tested by PCR, 42 isolate (84\%) were found to have the PSE gene, it is worth mentioning that the 8 PSE-negative isolates were susceptible to pipracillin. Cho et al. ${ }^{44}$ reported lower rate where only two out of 61 Psendomonas isolates (3.3\%) harbored PSE gene. The AmpC and PSE are the main hydrolyzing enzymes that confer $\beta$-lactam resistance in our study.

The efflux system contributes to the natural bacterial resistance to a wide range of antibiotics and detergents ${ }^{45}$, ${ }^{46}$. In our study, active efflux was detected in all isolates. This was in accordance with Rana et al. ${ }^{47}$ who reported presence of active efflux in all MDR isolates. Presence of MexABR efflux system was confirmed by amplification of this operon using multiplex PCR. All of the P. aeruginosa isolates were positive to the three tested genes. This was in accordance with Al-Grawi et al. ${ }^{24}$ who found that all of the $P$. aeruginosa isolates were positive to the three genes.

Our study also investigated the outer membrane reduced permeability as a resistance mechanism; assay was performed with EDTA as a permeabilizer. The MIC values for tested antibiotics was determined in the presence and absence of sub MIC (1/4 MIC) of EDTA. Our results showed that EDTA has augmenting effect on different anti-microbial agents; EDTA reduced the MICs of various anti-microbials by up to 16 folds. This was compa- 
rable with the results of Ayres et $a .^{48}$ who reported that EDTA was greatly enhanced the activity of various antibiotics and biocides against Gram negative isolates.

\section{Conclusion}

This study revealed that the resistance rates of local $P$. aeruginosa were higher than worldwide values. This high resistance was attributed to several mechanisms including efflux pumps, reduced activity of outer membrane porins, production of AmpC and PSE $\beta$-lactamases. This high MDR resistance rate is alarming which necessitates applying strict antibiotic usage and prescription policies. Also selection of curative antibiotics should depend on the anti-microbial susceptibility results.

\section{Conflict of interest}

The authors declare that they have no conflict of interest

\section{References}

1. Angadi KM , Kadam M, Modak M S, Bhatavdekar SM, Dalal B A, Jadhavvar SR et al. Detection of antibiotic resistance in Pseudomonas aeruginosa isolates with special reference to metallo-B-lactamases from a tertiary care hospital in Western India. International Journal of Microbiology Research. 2012; 4(7): 295-298.

2. Stamm WE, Norrby SR. Urinary tract infections: disease panorama and challenges. Journal of Infectious Diseases. 2001; 183 (Suppl. 1): S1-S4.

3. Jarvis WR, Martone WJ. Predominant pathogens in hospital infections. Journal of Antimicrobial Chemotherapy. 1992; 29: 19-24.

4. Mittal R, Aggarwal S, Sharma S, Chhibber S, Harjai K. Urinary tract infections caused by Pseudomonas aeruginosa: a minireview. Journal of Infection and Public Health. 2009; 2(3): 101-111.

5. Hanson ND. Editorial: Resistance in gram-negative pathogens: a threat to global health. Current Pharmaceutical Design. 2013; 19: 163.

6. Meletis G, Vavatsi N, Exindari M, Protonotariou E, Sianou E, Haitoglou $C$ et al. Accumulation of carbapenem resistance mechanisms in VIM-2-producing Pseudomonas aeruginosa under selective pressure. European Journal of Clinical Microbiology and Infectious Diseases. 2014; 33: 253258 PubMed .

7. Zeng Z R, Wang W P, Huang M, Shi LN, Wang Y, Shao HF. Mechanisms of carbapenem resistance in cephalo- sporin-susceptible Pseudomonas aeruginosa in China. Diagnostic Microbiology and Infectious Diseases. 2014; 78: 268-270. 8. Labby KJ, Garneau-Tsodikova S. Strategies to overcome the action of aminoglycoside-modifying enzymes for treating resistant bacterial infections. Future Medicinal Chemistry. 2013; 5: 1285-1309.

9. Aldred KJ, McPherson SA, Turnbough CL, Jr, Kerns RJ, Osheroff N. Topoisomerase IV-quinolone interactions are mediated through a water-metal ion bridge: mechanistic basis of quinolone resistance. Nucleic Acids Research 2013; 41: 4628-4639.

10. Chaudhary M, Payasi A. Rising antimicrobial resistance of Pseudomonas aeruginosa isolated from clinical specimens in India. Journal of Proteomics and Bioinformatics. 2013; 6: 005-009.

11. Strateva T, Yordanov D. Pseudomonas aeruginosa - a phenomenon of bacterial resistance. Journal of Medical Microbiology. 2009; 58: 1133-1148.

12. Upadhyay S, Sen MR, Bhattacharjee A. Presence of different $\beta$-lactamase classes among clinical isolates of Pseudomonas aeruginosa expressing AmpC $\beta$ - lactamase enzyme. The Journal of Infection in Developing Countries. 2010; 4: 239-242.

13. Altun S, Tufan ZK, Yağc1 S, ÖndeU, Bulut C, Kınıkl $\mathrm{S}$ et al. Extended spectrum Beta-lactamases, AmpC and metallo Beta-lactamases in emerging multi-drug resistant Gram-negative bacteria in intensive care units. Open Access Scientific Reports 2013; 2(4):707.

14. Poirel L, Nordmann P. Carbapenem resistance in Acinetobacter baumannii: mechanisms and epidemiology. Clinical Microbiology and Infection. 2006; 12: 826-836

15. Poole, K. Multidrug efflux pumps and antimicrobial resistance in Pseudomonas aeruginosa and related organisms. Journal of Molecular Microbiology and Biotechnology. 2001; 3: 255-264.

16. Lambert PA. Mechanisms of antibiotic resistance in Pseudomonas aeruginosa. Journal of The Royal Society of Medicine. 2002; 95: 22-26

17. Koneman E, Winn WJ. Koneman's Color Atlas and Textbook of Diagnostic Microbiology, 6th edn. Lippincott Williams \& Wilkins, London, 2006

18. Clinical and Laboratory Standards Institute. Performance Standards for Antimicrobial Susceptibility Testing; Twenty 2nd informational Supplement. CLSI document M100S22. Wayne, PA, USA, 2012.

19. Yong D, Lee K, Yum JH, Shin HB, Rossolini GM, 
Chong Y. Imipenem-EDTA disc method for differentiation of MBL-producing clinical isolates of Pseudomonas sp. and Acinetobacter sp. Journal of Clinical Microbiology. 2002; 40:3798-801.

20. Vanwynsberghe T, Verhamme K, Raymaekers M, Cartuyvels R, Vaerenberg KV, Boela A, de Beenhouwer $\mathrm{H}$. A large hospital outbreak of Klebsiella pneumoniae (DHA-1 and SHV-11 positive): Importance of detection and treatment of AmpC $\beta$-lactamases. The Open Infectious Disease Journal. 2009; 3: 55-60.

21. Clinical and Laboratory Standards Institute. Performance Standards for Antimicrobial Susceptibility Testing. Approved standards. In $11^{\text {th }}$ Edition document M02-A11. Wayne, PA, USA, 2013.

22. Martins M, Mccusker MP, Viveiros M, Couto I, Fanning S, Pages JM et al. A Simple method for assessment of MDR bacteria for over-expressed efflux pumps. Open Microbiology Journal. 2013; 7: 72-82.

23. Clinical and Laboratory Standards Institute. Methods for Dilution Antimicrobial Susceptibility Tests for Bacteria That Grow Aerobically; Approved Standard-Ninth Edition. CLSI document M07-A9. CLSI, Wayne, PA, USA, 2012.

24. Al-Grawi IGA, Al-Absali AK, Kareem NH, Belal SA. Occurrence of MexAB-OprM efflux pump operon on septicemic Pseudomonas aeruginosa chromosome. The Iraqi Postgraduate Medical Journal. 2012; 2: 97-102.

25. Rodríguez-Martínez JM, Poirel L, Nordmann P. Molecular epidemiology and mechanisms of carbapenem resistance in Pseudomonas aeruginosa. Antimicrobial agents and chemotherapy. 2009; 53(11), 4783-4788.

26. Fazeli H, Sadighian H, Nasr Esfahani B, Pourmand MR. Identification of class-1 integron and various $\beta$-lactamase classes among clinical isolates of Pseudomonas aeruginosa at children's medical center hospital. Journal of Medical Bacteriology. 2012; 1: 25-36. PubMed

27. Neyestanaki D K, Mirsalehian A, Rezagholizadeh F, Jabalameli F, Taherikalani M, Emaneini M. Determination of extended spectrum $\beta$-lactamases, metallo- $\beta$-lactamases and AmpC- $\beta$-lactamases among carbapenem resistant Pseudomonas aeruginosa isolated from burn patients. Burns. 2014; 40: 1556-1561.

28. Qing Y, Cao KY, Fang ZL, Huang YM, Zhang XF, Tian GB et al. Outbreak of PER-1 and diversity of $\beta$-lactamases among ceftazidime-resistant Pseudomonas aeruginosa clinical isolates. Journal of Medical Microbiology. 2014; 63: 386-392.
29. Poirel L, Walsh TR, Cuvillier V, Nordmann P. Multiplex PCR for detection of acquired carbapenemase genes. Diagnostic Microbiology and Infectious Diseases. 2011; 70: 119-123.

30. Daniel SA, Shawky MS, Omar HMG, Abou-Shleib HM, El-Nakeeb MA. Antibiotic resistance and its association with biocide susceptibilities among microbial isolates in an Egyptian hospital. The international Arabic Journal of antimicrobialagents. 2015; 4: 1-11.

31. Mahmoud AB, Zahran WH, Hindawi GR, Labib AZ, Galal R. Prevalence of Multidrug-Resistant Pseudomonas aeruginosa in patients with nosocomial infections at a University hospital in Egypt, with special reference to typing methods. Journal of Virology and Microbiology. 2013; Article ID 290047: 13 pages.

32. Hassuna NA, Mohamed AHI, Abo-Eleuoon SM, Rizk HA. High Prevalence of multidrug resistant Pseudomonas aeruginosa recovered from infected burn wounds in children. AC Microbiology. 2015; 6(4): 1-7. PubMed

33. Kadry AA, Serry FM, El-Ganiny AM, El-Baz AM. Integron occurrence is linked to reduced biocide susceptibility in multidrug resistant Pseudomonas aeruginosa. British Journal of biomedical sciences. 2017; 74(2): 78-84.

34. Zhanel, GG, DeCorby M, Adam H, Mulvey MR, McCracken M, Lagacé-Wiens P et al. Prevalence of antimicrobial-resistant pathogens in Canadian hospitals: results of the Canadian Ward Surveillance Study (CANWARD 2008). Antimicrobial agents and Chemotherapy. 2010; 54(11): 4684-4693.

35. Narten M, Rosin N, Schobert M, Tielen P. Susceptibility of Pseudomonas aeruginosa urinary tract isolates and influence of urinary tract conditions on antibiotic tolerance. Current microbiology, 2012; 64(1): 7-16.

36. Pathmanathan SG, Samat NA, Mohamed R. Antimicrobial susceptibility of clinical isolates of Psendomonas aeruginosa from a Malaysian hospital. Malaysian Journal of Medical Sciences. 2009; 16(2): 27-32.

37. Anil C, Shahid RM. Antimicrobial susceptibility patterns of Pseudomonas aeruginosa clinical isolates at a tertiary care hospital in Kathmandu, Nepal. Asian Journal of Pharmacy and Clinical Research. 2013; 6(3): 235-238.

38. Hirsch E B, Tam VH. Impact of multidrug-resistant Pseudomonas aeruginosa infection on patient outcomes. Expert review of pharmacoeconomics \& outcomes research 2010; 10(4): 441-451.

39. Arunagiri K, Sekar B, Sangeetha G, John J. Detection and Characterization of Metallo- $\beta$-lactamases in Pseudo- 
monas aeruginosa by Phenotypic and Molecular Methods from Clinical Samples in a Tertiary Care Hospital. West Indian Medical Journal. 2012; 61(8):778-783.

40. Zafer MM, Al-Agamy MH, El-Mahallawy HA, Amin MA, Ashour MS. Anti-microbial resistance pattern and their beta-lactamase encoding genes among Pseudomonas aeruginosa strains isolated from cancer patients. Biomed Research International. 2014; Article ID 101635: 8 pages 41. Meletis G, Exindari M, Vavatsi N, Sofianou D, Diza E. Mechanisms responsible for the emergence of carbapenem resistance in Pseudomonas aeruginosa. Hippokratia. 2012; 16(4): 303-307

42. Lin S, Liu M, Lin C, Shi Z. Phenotypic detection and polymerase chain reaction screening of extended-spectrum b-lactamases produced by Pseudomonas aeruginosa isolates. Journal of Microbiology, Immunology and Infection. 2012; 45: 200-207

43. Chika E, Charles E, Ifeanyichukwu I, Chigozie U, Chika F, Carissa D et al. Phenotypic detection of AmpC Beta-lactamase among anal Pseudomonas aeruginosa isolates in a Nigerian Abattoir. Archieve of Clinical Microbiology. 2016; 7:2.
44. Cho HH, Kwon GC, Kim S, Koo SH. Distribution of Pseudomonas-derived cephalosporinase and metallo- $\beta$-Lactamases in carbapenem-resistant Pseudomonas aeruginosa isolates from Korea. Journal of Microbiology and Biotechnology. 2015; 25(7): 1154-1162

45. Hirakata Y, Srikumar R, Poole K, Gotoh N, Suematsu T, Kohno $\mathrm{S}$ et al. Multidrug efflux systems play an important role in the invasiveness of Pseudomonas aeruginosa. Journal of Experimental Medicine. 2002; 196: 109-118.

46. Gorgani NN. Detection mutations related to antibiotic resistance in Pseudomonas aeruginosa. The Faculty of the Department of Biological Sciences. San Jose State University. M.Sc, 2009.

47. Rana T, Kaur N, Farooq U, Khan A, Singh S. Efflux as an arising cause of drug resistance in Punjab (India). International Journal of Biology, Pharmacy and Allied Sciences. 2015; 4(9): 5967-5979.

48. Ayres H, Furr J, Russell A. Effect of permeabilizers on antibiotic sensitivity of Pseudomonas aeruginosa. Letters in Applied Microbiology. 1999; 28: 13-16. 